\title{
Evaluation of Screening Methods for the Isolation of Biosurfactant Producing Marine Bacteria
}

\author{
Rengathavasi Thavasi ${ }^{1 *}$, Shilpy Sharma ${ }^{1}$ and Singaram Jayalakshmi
}

${ }^{1}$ Department of Chemical and Biological Sciences, Polytechnic Institute of New York University, 6 Metrotech Center, Brooklyn, New York 11201, USA ${ }^{2}$ CAS in Marine Biology, Annamalai University, Parangipettai 608502, TN, Indi

\begin{abstract}
Hemolytic assay, bacterial adhesion to hydrocarbons (BATH) assay, drop collapse assay, oil spreading assay, emulsification assay and surface tension measurement were compared for their reliability and ease of use to screen biosurfactant producing bacteria. 105 bacterial strains were screened for their biosurfactant production. Results from screening methods revealed that hemolytic and BATH assays are not reliable methods to check biosurfactant production because hemolytic assay relies on lysis of blood cells, which can be caused by compounds produced by microbes other than the biosurfactants. In that case hemolytic assay may include strains that do not produce biosurfactant. BATH assay relies on hydrophobicity or adherence of cells with hydrophobic compounds. Results obtained in BATH assay for three bacterial isolates, Branhamella catarrhalis, Citrobacter intermedius and Klebsiella ozaenae were positive, but when the same isolates screened for drop collapse, oil spreading, and surface tension measurement the results were negative. This indicates that these bacterial cells are either acting as biosurfactant themselves (cell surface) or they don't have the ability to produce biosurfactants. In conclusion, drop collapse and oil spreading assays are reliable methods to screen large number of samples. However, for confirmation surface tension measurement can be used at the end. Another interesting finding in this study was the use of crude oil as hydrophobic substrate for the isolation of biosurfactant producing bacterial strains; this approach may be useful during the initial isolation of biosurfactant producing bacteria to reduce the number of strains to be screened.
\end{abstract}

Keywords: Biosurfactants; Emulsification; Drop collapse; Oil spreading; Hemolysis

\section{Introduction}

Bacteria produce a wide range of extracellular products with many properties and applications. Biosurfactants are one such extracellular amphiphilic compounds produced by bacteria, yeast and fungi, especially when they are grown on hydrophobic substrates. Biosurfactants are surface active compounds produced by microorganisms. They reduce surface and interfacial tension by accumulating at the interface of immiscible fluids and thus increase the solubility, bioavailability and subsequent biodegradation of the hydrophobic or insoluble organic compounds [1]. There are many types of biosurfactants based on their chemical nature such as glycolipids, lipopolysaccharides, oligosaccharides and lipopeptides that have been reported to be produced by diverse bacterial genera [2-4]. Biosurfactants have received considerable attention in the field of environmental remediation processes such as biodegradation, soil washing and soil flushing. Biosurfactants influence these processes because of their efficacy as dispersion and remediation agents and their environmentally friendly characteristics such as low toxicity and high biodegradability [5-9]. There are many reports describing the effect of exogenously added microbial biosurfactants in enhancing the bioremediation of crude oil-polluted soils by indigenous microbes [10-12] and how to purify and detect these biosurfactants [13-15]. Biosurfactants are potential antimicrobial agents to specific microbes and thus can be exploited for its antimicrobial applications against plant, animal and human microbial pathogens [1].

Due to their unique properties and vast array of application, identification of new biosurfactant producing microbes is in great demand. There are nine different screening methods that have been reported as criteria to screen biosurfactant producing microbes such as hemolytic assay [16,17], bacterial adhesion to hydrocarbons (BATH) assay [18,19], drop collapse assay, oil spreading assay $[20,21]$, emulsification assay [22,23], surface tension measurement, titled glass slide test, blue agar plate and hydrocarbon overlay agar assay [23]. Methods discussed above have both advantages and disadvantages. Methods like hemolytic assays are not reliable and sensitive, because this method will categorize microbes in two groups as hemolytic and nonhemolytic. Strains that are hemolytic are believed to be biosurfactant producers, but there are other products such as virulence factors that can lyse the blood cells and also biosurfactants with poor diffusion in agar may not be able to lyse the blood cells. Thus, the results from hemolytic assay on blood agar plate are not so reliable and sensitive. So there is a need to find robust, sensitive and easy to perform, collection of methods to screen biosurfactant producing microbes. This study was conducted to find sensitive, reproducible and easy to perform assay methods to screen biosurfactant producing bacteria. Screening criteria used in this study include: hemolytic assay, BATH assay, drop collapse assay, oil spreading assay, emulsification assay and surface tension measurement. Total of 105 different bacterial strains were screened to check their biosurfactant production using aforementioned six methods. From the results, it was found that the drop collapse and oil spreading assays directly correlated to each other and easy to perform without any specialized equipments. However, surface

*Corresponding author: Rengathavasi Thavasi, 1Department of Chemical and Biological Sciences, Polytechnic Institute of New York University, 6 Metrotech Center, Brooklyn, New York 11201, USA, Tel: +1 718-260-3960; Fax: +1 718-2603075; E-mail: hydrobact@gmail.com

Received October 21, 2011; Accepted November 10, 2011; Published November 12, 2011

Citation: Thavasi R, Sharma S, Jayalakshmi S (2011) Evaluation of Screening Methods for the Isolation of Biosurfactant Producing Marine Bacteria. J Pet Environ Biotechnol S1:001. doi:10.4172/2157-7463.S1-001

Copyright: @ 2011 Thavasi $R$, et al. This is an open-access article distributed under the terms of the Creative Commons Attribution License, which permits unrestricted use, distribution, and reproduction in any medium, provided the original author and source are credited. 
tension measurement results also had a direct correlation with drop collapse and oil spreading assays, but it needs a surface tensiometer to perform the assay, which may not be readily available in a microbiology laboratory. Apart from above mentioned screening methods, this study also analyzes the credibility of the use of hydrophobic substrates like crude oil for the isolation of biosurfactant producing bacteria from the environment.

\section{Material and Methods}

\section{Microorganism}

Bacterial cultures used in this study were isolated from sea water samples collected at Tuticorin harbor ( $\left.08^{\circ} 45^{\prime} \mathrm{N} ; 7^{\circ} 13^{\prime} \mathrm{E}\right)$, South East coast of India using Bushnell Haas agar enriched with $0.1 \%$ crude oil. Total of 105 bacterial strains were isolated and identified to their species level and reported elsewhere [24]. In above study, Thavasi and Jayalakshmi [24] isolated the strains to check their crude oil degradation, whereas in this study the same isolates were screened for their biosurfactant production and to prove the concept of use of hydrophobic substrates as an effective screening tool for the isolation of biosurfactant producing bacteria.

\section{Screening for biosurfactant production}

Culture medium and bacterial growth: Bacteria were grown aerobically in $500 \mathrm{ml}$ Erlenmeyer flask with $100 \mathrm{ml}$ of mineral salt medium containing $\left(\mathrm{g} \mathrm{l}^{-1}\right) 1.0 \mathrm{~K}_{2} \mathrm{HPO}_{4}, 0.2 \mathrm{MgSO}_{4} .7 \mathrm{H}_{2} \mathrm{O}, 0.05$ $\mathrm{FeSO}_{4} \cdot 7 \mathrm{H}_{2} \mathrm{O}, 0.1 \mathrm{CaCl}_{2} \cdot 2 \mathrm{H}_{2} \mathrm{O}, 0.001 \mathrm{Na}_{2} \mathrm{MoO}_{4} \cdot 2 \mathrm{H}_{2} \mathrm{O}, 30 \mathrm{NaCl}$ and crude oil $(1.0 \%, \mathrm{w} / \mathrm{v})$. Crude oil used in this study was obtained from Chennai Refineries Limited, Chennai, India with a specific gravity of 0.844 at $25^{\circ} \mathrm{C}$. Flasks containing sterilized mineral salt medium were inoculated with a loopful of bacterial culture grown in crude oil containing nutrient agar plates and the culture flasks were maintained in a shaker for 7 days at $200 \mathrm{rpm}$ and $30^{\circ} \mathrm{C}$. After 7 days of incubation, culture broth from each flask was centrifuged at $6000 \mathrm{rpm}$ and $4^{\circ} \mathrm{C}$ for 15 minutes and the supernatant was filtered through $0.45 \mu \mathrm{m}$ pore size filter paper (Millipore). This cell free culture broth was used for drop collapse assay, oil spreading assay, emulsification assay and surface tension measurement and the bacterial cells were used for hemolytic and BATH assay. All the screening experiments were performed in triplicates (until otherwise mentioned) and the mean values were used as results.

\section{Hemolytic activity}

Hemolytic assay was performed in 5\% sheep blood agar plates [25]. $50 \mu \mathrm{l}$ of bacterial culture grown in mineral salt medium was spotinoculated on to blood agar plates and incubated for $48 \mathrm{~h}$ at $37^{\circ} \mathrm{C}$. The plates were visually inspected for clear zone (hemolysis) around the colony. The diameter of the clear zone is a qualitative method used as an indicator of biosurfactant production $[25,26]$.

\section{BATH assay}

Cell hydrophobicity was measured by bacterial adherence to hydrocarbons according to a method described by Rosenberg et al. [27]. The cell pellets collected in the above culture medium and bacterial growth section (in materials and methods) were washed twice and suspended in a buffer salt solution $\left(\mathrm{g} \mathrm{l}^{-1}, 16.9 \mathrm{~K}_{2} \mathrm{HPO}_{4}\right.$ and $7.3 \mathrm{KH}_{2} \mathrm{PO}_{4}$ ) and diluted using the same buffer solution to an optical density (OD) of $\sim 0.5$ at $610 \mathrm{~nm}$. To the cell suspension $(2 \mathrm{ml})$ in test tubes ( $10 \mathrm{ml}$ volume with $10 \times 100 \mathrm{~mm}$ dimension) $100 \mu \mathrm{l}$ of crude oil was added and vortex-shaken for $3 \mathrm{~min}$. After shaking, crude oil and aqueous phases were allowed to separate for $1 \mathrm{~h}$. OD of the aqueous phase was then measured at $610 \mathrm{~nm}$ in a spectrophotometer (Varian, Cary Eclipse Spectrophotometer). From the OD values, percentage of cells attached to crude oil was calculated using the following formula:

$\%$ of bacterial cell adherence $=\left(1-\left(\mathrm{OD}_{\text {shaken with oil }} / \mathrm{OD}_{\text {original }}\right)\right) \times 100$

Where: $\mathrm{OD}_{\text {shaken with oil }}$ - $\mathrm{OD}$ of the mixture containing cells and crude oil

$\mathrm{OD}_{\text {original }}$ - $\mathrm{OD}$ of the cell suspension in the buffer solution (before mixing with crude oil)

A few drops of 2-(4-iodophenyl)-3-(4-nitrophenyl)-5phenyltetrazolium chloride (INT) solution was added to the above BATH assay solution and observed under a light microscope. The INT turned red if it was reduced inside the cells, indicating the viability of the cells adhered to the crude oil droplets [28].

\section{Drop collapse test}

Drop collapse test was performed by following the procedure described by Jain et al. [29] and modified by Bodour and Miller-Maier [20]. $2 \mu \mathrm{l}$ of crude oil was applied to the well regions delimited on the covers of 96-well micro-plate lids and allowed to equilibrate for $24 \mathrm{~h}$. Five microliters of the cell free culture broth was transferred to the oilcoated regions and the drop size was observed 1 min later with the aid of a magnifying glass. A result was considered positive for biosurfactant production when the drop diameter was at least $1 \mathrm{~mm}$ larger than that produced by de-ionized water (negative control). Triton X-100 (a chemical surfactant) solution prepared at $1 \mathrm{mg} / \mathrm{ml}$ concentration was used as a standard.

\section{Oil spreading assay}

Oil spreading experiment was performed using the method described by Morikawa et al. [30]. In brief, $20 \mathrm{ml}$ of distilled water was added to a plastic Petri dish followed by addition of $20 \mu \mathrm{l}$ of crude oil to the surface of the water. $10 \mu \mathrm{l}$ of cell free culture broth was then added to the oil surface. If biosurfactant is present in the cell free culture broth, the oil will be displaced with an oil free clearing zone and diameter of this clearing zone indicates the surfactant activity, also called oil displacement activity. A negative control was maintained with distilled water (without surfactant), in which no oil displacement or clear zone was observed and Triton X-100 was used as the positive control.

\section{Emulsification assay}

Cell free culture broth was used as the biosurfactant source to check the emulsification of crude oil. $1 \mathrm{ml}$ of cell free culture broth was added to $5 \mathrm{ml}$ of $50 \mathrm{mM}$ Tris buffer ( $\mathrm{pH} 8.0$ ) in a $30 \mathrm{ml} \mathrm{screw-capped} \mathrm{test} \mathrm{tube.}$ Five milligram of hydrocarbon was added to the above solution and vortex-shaken for 1 minute and the emulsion mixture was allowed to stand for 20 minutes. OD of the emulsion mixture was measured at 610 $\mathrm{nm}$ in a spectrophotometer and the results were expressed as $\mathrm{D}_{610}[31]$. A negative control was maintained only with buffer solution and crude oil and Triton X-100 was used as the positive control.

\section{Surface tension measurement}

Surface tension measurement of cell-free culture broth from each strain was determined in a K6 tensiometer (Krüss GmbH, Hamburg, Germany), using the du Nouy ring method. Triton X-100 solution prepared at $1 \mathrm{mg} / \mathrm{ml}$ concentration was used as a standard. 


\section{Results and Discussion}

\section{Microorganisms}

Oil degrading and total heterotrophic bacteria isolated from the sea water sample were $1.05 \times 10^{3}$ and $2.13 \times 10^{5} \mathrm{CFU} / \mathrm{ml}$, respectively. Percentage calculation showed that oil degrading bacteria contributed $0.5 \%$ of the total heterotrophic bacterial $(99.5 \%)$ population in the water sample. All the 105 oil degrading bacterial strains isolated in Bushnell Haas agar were subjected to screening for their biosurfactant production. Results on identification of 105 bacterial strains revealed that out of 105 isolates, 34 strains belong to gram positive and 71 strains to gram negative group represented by 18 bacterial species from 11 genera. Scientific names of the isolated bacterial species and number of isolates from each species (values in bracket) were as follows: Bacillus cereus (3), B. megaterium (3), B. subtilis (4), Branhamella catarrhalis (2), Citrobacter intermedius (5), Corynebacterium kutscheri (15), C. xerosis (2), Enterobacter aerogenes (2), Escherichia coli (6), Klebsiella ozaenae (5), Lactobacillus casei (2), L. delbrueckii (2), Proteus inconstans (6), Pseudomonas aeruginosa (23), P. fluorescens (1), P. diminuta (12), P. mallei (9) and Staphylococcus aureus (3). Species dominance results showed that among the 105 strains isolated, 45 strains belong to the genus Pseudomonas (42.8\%) in which Pseudomonas aeruginosa was found as the dominant species [24]. Dominant existence and biosurfactant producing Pseudomonas strains in hydrocarbon polluted environment was reported by many researchers [32-34] supporting the results obtained in this study.

\section{Screening for biosurfactant production}

Hemolytic assay: From 105 bacterial strains tested, 101(96.1\%) strains were positive for hemolysis and P. aeruginosa showed the maximum hemolytic activity of $3.05 \mathrm{~cm}$ and E. aerogenes and L. casei showed the least activity of $1.15 \mathrm{~cm}$ (Table 1). Reason for using hemolytic assay in this study as a criterion for biosurfactant production was because it is a widely used method to screen biosurfactant production and in some reports it is the sole method used to screen biosurfactant production [16,17]. The hemolytic activity of biosurfactants was first discovered when Bernheimer and Avigad [35] reported that the biosurfactant produced by B. subtilis, surfactin, lysed red blood cells. Carrillo et al. [36] found an association between hemolytic activity and surfactant production and they recommended the use of blood agar lysis as a primary method to screen biosurfactant production. None of the studies reported in the literature [21-23,36-38] mention the possibility of biosurfactant production without a hemolytic activity. However, in some studies hemolytic assay excluded many good biosurfactant producers and in some reports strains with positive hemolytic activity were found negative for biosurfactant production [21]. In addition, not all biosurfactants have hemolytic activity and compounds other than biosurfactants may cause hemolysis. Hence, in the present investigation BATH assay, drop collapse test, oil spreading assay, emulsification assay and surface tension measurements were included to confirm biosurfactant production.

\section{BATH assay}

Rosenberg et al. [27] developed a procedure to estimate the cell hydrophobicity. Cell adherence with hydrophobic compounds like crude oil is considered as an indirect method to screen bacteria for biosurfactant production, because cells attach themselves with oil droplets by producing surface active compounds called biosurfactants. BATH assay conducted in this study with 105 isolates revealed that

\begin{tabular}{|l|c|c|}
\hline \multicolumn{1}{|c|}{$\begin{array}{c}\text { Name of bacteria and } \\
\text { total number of strains }\end{array}$} & Hemolytic assay & BATH assay \\
& & \\
\hline Bacillus cereus (3) & $+(2)$ & $+(2)$ \\
& $++(1)$ & $++(1)$ \\
B. megaterium & $++(2)$ & $++(2)$ \\
& $+++(1)$ & $+++(1)$ \\
B. subtilis (4) & $++(1)$ & $++(2)$ \\
& $+++(3)$ & $+++(2)$ \\
Branhamella catarrhalis (2) & $+(2)$ & $+(2)$ \\
Citrobacter intermedius (5) & $+(2)$ & $+(2)$ \\
& $++(3)$ & $++(2)$ \\
Corynebacterium kutscheri (15) & $++(5)$ & $++(10)$ \\
& $+++(10)$ & $+++(2)$ \\
C. xerosis (2) & $+(2)$ & $+(1)$ \\
& & $++(1)$ \\
Enterobacter aerogenes (2) & $+(1)$ & $+(2)$ \\
& $++(1)$ & $+(3)$ \\
Escherichia coli (6) & $+(4)$ & $++(1)$ \\
& $++(2)$ & $++(5)$ \\
Klebsiella ozaenae (5) & $++(4)$ & $+(2)$ \\
& $+++(1)$ & $++(2)$ \\
Lactobacillus casei (2) & $+(1)$ & $+(4)$ \\
L. delbrueckii (2) & $++(2)$ & $++(19)$ \\
Proteus inconstans (6) & $+(5)$ & $+++(4)$ \\
Pseudomonas aeruginosa (23) & $+(5)$ & $++(1)$ \\
P. fluorescens (1) & $++(7)$ & $+(11)$ \\
P. diminuta (12) & $+++(11)$ & $+(5)$ \\
P. mallei (9) & $++(1)$ & $+(2)$ \\
Staphylococcus aureus (3) & $+(5)$ & $++(4)$ \\
\hline
\end{tabular}

Hemolytic assaya: '+' - hemolysis with a clear zone of $1-1.5 \mathrm{~cm}$, '++' - hemolysis with a clear zone of $1.6-2.5 \mathrm{~cm}$, '+++ - hemolysis with a clear zone of $2.6-3.5 \mathrm{~cm}$. BATH assay': '+++' - cell adhesion > $90 \%$, ' '++' - 60 to $89 \%$ cell adhesion, ' '' - 40 to $59 \%$ cell adhesion.

Values in () near '+' sign are the number of positive strains in that category. Values in () near bacterial name are the total number of strains isolated.

Table 1: Hemolytic and BATH assay.

91 (86.6\%) bacterial strains were positive for the BATH assay, which indicated the affinity of the bacterial cells towards hydrophobic substrate. Cell adherence found for above positive strains with crude oil was in the range of $34 \pm 1.41$ to $95.15 \pm 0.21 \%$. Maximum cell attachment with crude oil was found with P. aeruginosa $(95.15 \pm 0.21 \%)$ followed by L. delbrueckii $(92.6 \pm 0.84 \%)$ (Table 1). Strains of Pseudomonas genus showed highest cell adherence with crude oil than other bacterial strains screened, which is complemented by other earlier reports on cell hydrophobicity and biosurfactant production by Pseudomonas strains $[19,39,40]$. Bacterial strains with high cell hydrophobicity are reported as potential biosurfactant producers [18,19] and in some reports BATH assay was used as a principle method to screen biosurfactant production [18]. While correlating the BATH assay results with hemolytic assay, strains with hemolytic activity of 1.75 \pm 0.07 to $3.05 \pm 0.07 \mathrm{~cm}$ showed high cell hydrophobicity and their cell adhesion was in the range of $41.1 \pm 1.27$ to $95.15 \pm 0.21 \%$, which indicated a positive correlation between hemolytic assay and BATH assay. Positive cell hydrophobicity was reported as an indication of biosurfactant production [41]. Visualization of bacterial cells adhered to crude oil confirmed the affinity of cells towards crude oil droplets.

\section{Emulsification assay}

Emulsification assay is an indirect method used to screen biosurfactant production. It was assumed that if the cell free culture broth used in this assay contains biosurfactant then it will emulsify the hydrocarbons present in the test solution. In this study, crude oil was used as the hydrophobic substrate. Results observed in this study revealed that from 105 strains screened, 85(80.9\%) strains showed 
Citation: Thavasi R, Sharma S, Jayalakshmi S (2011) Evaluation of Screening Methods for the Isolation of Biosurfactant Producing Marine Bacteria. J Pet Environ Biotechnol S1:001. doi:10.4172/2157-7463.S1-001

Page 4 of 6

positive emulsification activity. No emulsification activity was found with the following 20 (19.1\%) strains namely Citrobacter intermedius (1), Corynebacterium kutscheri (3), Escherichia coli (3), Klebsiella ozaenae (all 5 strains), Proteus inconstans (2), Pseudomonas diminuta (2) and Staphylococcus aureus (2). 5 strains from K. ozaenae species were positive for both hemolytic and BATH assay where as all of them were negative for emulsification assay. Thus, hemolytic and BATH assays are not very reliable methods to test the biosurfactant production and which also inferred that extracellular products other than biosurfactants are responsible for the positive hemolytic and BATH activity observed with the strains showing negative emulsification activity. Three P. aeruginosa strains showed the highest emulsification activity of $\mathrm{D}_{610} 1.95 \pm 0.5$ (Table 2).

\section{Drop collapse test}

Drop collapse method is a sensitive and easy to perform method which requires small volume $(\sim 5 \mu)$ of culture broth or biosurfactant solution to test the surfactant property. Among the 105 strains screened, $82(78.1 \%)$ strains were positive for drop collapse activity (Table 3 ). All 12 strains from three species namely, Branhamella catarrhalis (2), Citrobacter intermedius (5) and Klebsiella ozaenae (5) were negative for drop collapse activity, but they were all positive for hemolytic and BATH assays. The reason behind the negative drop collapse and positive hemolytic and BATH results obtained with above 12 strains might be that some bacterial cells act as biosurfactant themselves [42] and have high cell hydrophobicity, but do not produce extracellular biosurfactants. In this experiment cell free culture broth was used as the biosurfactant source. For strains which produce extracellular biosurfactant there was a drop collapse activity and for strains which do not produce biosurfactant the results were negative, which also inferred that to check the biosurfactant production of any microbial strain, cell free culture broth should be used instead of using culture

\begin{tabular}{|l|c|}
\hline \multicolumn{1}{|c|}{$\begin{array}{c}\text { Name of bacteria and } \\
\text { total number of strains }\end{array}$} & Emulsification assay $\mathbf{D}_{160}{ }^{a}$ \\
\hline Bacillus cereus (3) & $+(1)$ \\
B. megaterium & $++(2)$ \\
& $++(2)$ \\
B. subtilis (4) & $+++(1)$ \\
& $++(2)$ \\
Branhamella catarrhalis (2) & $+++(2)$ \\
Citrobacter intermedius (5) & $\mathrm{NA}$ \\
& $+(2)$ \\
Corynebacterium kutscheri (15) & $++(2)$ \\
& $++(10)$ \\
C. xerosis (2) & $+++(2)$ \\
& $+(1)$ \\
Enterobacter aerogenes (2) & $++(1)$ \\
Escherichia coli (6) & $+(2)$ \\
Klebsiella ozaenae (5) & $+(3)$ \\
Lactobacillus casei (2) & $\mathrm{NA}$ \\
L. delbrueckii (2) & $+(2)$ \\
Proteus inconstans (6) & $++(2)$ \\
Pseudomonas aeruginosa (23) & $+(4)$ \\
P. fluorescens (1) & $++(20)$ \\
P. diminuta (12) & $+++(3)$ \\
P. mallei (9) & $+(1)$ \\
Staphylococcus aureus (3) & $+(10)$ \\
Triton X-100 & $+(9)$ \\
\hline & $+(1)$ \\
Em & +++ \\
\hline
\end{tabular}

Emulsification assaya: 'NA' - no emulsification, '+++'- emulsification activity $D_{610}$ $>3$, ' ++ ' - $D_{610} 2$ to 2.9 , and '+' - $D_{610} 0.5$ to 2 .

Values in () near '+' sign are the number of positive strains in that category.

Values in () near bacterial name are the total number of strains isolated.

Table 2: Emulsification assay.

\begin{tabular}{|c|c|c|c|}
\hline $\begin{array}{c}\text { Name of bacteria and total } \\
\text { number of strains }\end{array}$ & $\begin{array}{c}\text { Drop collapse } \\
\text { assay }^{\mathrm{a}}\end{array}$ & $\begin{array}{l}\text { Oil spreading } \\
\text { assayb }^{\mathrm{b}}\end{array}$ & $\begin{array}{l}\text { Surface } \\
\text { tension } \\
(\mathrm{mN} / \mathrm{m})^{\mathrm{c}}\end{array}$ \\
\hline Bacillus cereus ( 3 ) & $+(2)$ & $+(2)$ & $\begin{array}{c}+(1) \\
++(2)\end{array}$ \\
\hline B. megaterium & $\begin{array}{c}++(1) \\
+++(2)\end{array}$ & $\begin{array}{c}++(1) \\
+++(2)\end{array}$ & $\begin{array}{c}+(1) \\
+++(2)\end{array}$ \\
\hline B. subtilis (4) & $\begin{array}{l}++(1) \\
+++(3)\end{array}$ & $\begin{array}{l}++(2) \\
+++(2)\end{array}$ & $\begin{array}{l}+(2) \\
++(2)\end{array}$ \\
\hline $\begin{array}{l}\text { Branhamella catarrhalis (2) } \\
\text { Citrobacter intermedius (5) }\end{array}$ & $\begin{array}{l}\text { NA } \\
\text { NA }\end{array}$ & $\begin{array}{l}\text { NA } \\
\text { NA }\end{array}$ & $\begin{array}{l}\text { NA } \\
\text { NA } \\
\text { NA }\end{array}$ \\
\hline $\begin{array}{l}\text { Corynebacterium kutscheri } \\
\text { (15) }\end{array}$ & $\begin{array}{l}++(4) \\
+++(11) \\
+(1)\end{array}$ & $\begin{array}{l}++(3) \\
+++(12) \\
+(1)\end{array}$ & $\begin{array}{l}++(13) \\
+++(2) \\
+(1)\end{array}$ \\
\hline C. xerosis (2) & $+(2)$ & $+(2)$ & $\begin{array}{l}++(1) \\
+(2)\end{array}$ \\
\hline Enterobacter aerogenes (2) & $+(5)$ & $+(5)$ & $+(3)$ \\
\hline $\begin{array}{l}\text { Escherichia coli }(6) \\
\text { Klebsiella ozaenae (5) }\end{array}$ & $\begin{array}{l}\text { NA } \\
+(1)\end{array}$ & $\begin{array}{l}\text { NA } \\
+(1)\end{array}$ & $\begin{array}{l}\text { NA } \\
+(2)\end{array}$ \\
\hline Lactobacillus casei (2) & $++(2)$ & $++(2)$ & $++(2)$ \\
\hline L. delbrueckii (2) & $+(5)$ & $+(5)$ & $+(4)$ \\
\hline Proteus inconstans (6) & $++(5)$ & $++(4)$ & $++(3)$ \\
\hline $\begin{array}{l}\text { Pseudomonas aeruginosa } \\
\text { (23) }\end{array}$ & $\begin{array}{c}+++(18) \\
++(1) \\
+(10)\end{array}$ & $\begin{array}{c}+++(19) \\
++(1) \\
+(10)\end{array}$ & $\begin{array}{c}+++(20) \\
+(1) \\
+(10)\end{array}$ \\
\hline P. fluorescens (1) & $+(6)$ & $+(5)$ & $+(4)$ \\
\hline P. diminuta $(12)$ & $+(2)$ & $+(2)$ & $+(1)$ \\
\hline $\begin{array}{l}\text { P. mallei (9) } \\
\text { Staphylococcus aureus (3) } \\
\text { Triton X-100 }\end{array}$ & +++ & +++ & +++ \\
\hline
\end{tabular}

Drop collapse assaya: 'NA'- no drop collapse activity, '+++'- drop collapse within 1 minute, '++'- drop collapse after 1 minute and '+' - drop collapse after 3 minutes of biosurfactant addition.

Oil spreading assay': 'NA' - no oil spreading activity, ' + ' - oil spreading with a clear zone of $0.5-1.5 \mathrm{~cm}$, '++' - oil spreading with a clear zone of 1.6 to $2.5 \mathrm{~cm}$, '+++' - oil spreading with a clear zone of 2.6 to $3.5 \mathrm{~cm}$.

Surface tension': 'NA'- no surfactant activity, '+++'- surface tension $<40 \mathrm{mN} / \mathrm{m}$ '++'- surface tension 40 to 50 ,' + '- surface tension 51 to 70 .

Values in () near '+' sign are the number of positive strains in that category. Values in () near bacterial name are the total number of strains isolated.

Table 3: Drop collapse, oil spreading assays and surface tension measurement.

broth with cells. This criterion will exclude microbial strains having high cell hydrophobicity and hemolytic activity but no biosurfactant production. Accuracy and reliability of results obtained in drop collapse assay in this study was similar to the results reported by Bodour and Miller-Maier [20].

Another merit associated with drop collapse assay is the sample volume required to check the drop collapse. 5 to $10 \mu \mathrm{l}$ of surfactant solution is enough to conduct a duplicate measurement. To further confirm the biosurfactant production of above strains with positive and negative results, cell free culture broth from all 105 bacterial strains was subjected to oil spreading and surface tension measurement experiments.

\section{Oil spreading assay}

Oil spreading assay results were in corroboration with drop collapse assay results. Strains found with positive drop collapse results were positive for oil spreading assay also (Table 3). These results confirmed the presence (for strains with positive results) and absence (for strains with negative results) of surface active compound (biosurfactant) in the cell free culture broth. Morikawa et al. [30] reported that the area of oil displacement in oil spreading assay is directly proportional to the concentration of the biosurfactant in the solution. However, in this study there was no quantitative study conducted on biosurfactant concentration versus oil spreading activity, but a qualitative study to check the presence of biosurfactant in the cell free culture broth was in 
concurrence with the above mentioned earlier report. As found in drop collapse assay, 12 strains from Branhamella catarrhalis, Citrobacter intermedius, Klebsiella ozaenae showed no oil spreading activity and in total out of 105 strains, 81 (77.1\%) strains were positive for the oil spreading assay. 5 strains namely Bacillus megaterium, B. subtilis, Corynebacterium kutscheri, Lactobacillus delbrueckii, Pseudomonas aeruginosa and $\mathrm{P}$. fluorescens showed highest oil spreading activity. Similar results with drop collapse and oil spreading assay was reported by Youssef et al. [21] while screening bacteria for biosurfactant production and also recommended that both drop collapse and oil spreading assay methods as reliable techniques for testing biosurfactant production.

\section{Surface tension measurement}

Surface tension measurement of cell free culture broth revealed that out of 105 strains screened, 79 (75.2\%) strains showed reduction in surface tension and highest surface tension reduction was observed with 5 strains namely Bacillus megaterium $(30.8 \pm 1.13 \mathrm{mN} / \mathrm{m})$, B. subtilis $(38.75 \pm 0.3 \mathrm{mN} / \mathrm{m})$, Corynebacterium kutscheri $(36.9 \pm 0.77 \mathrm{mN} / \mathrm{m})$, C. xerosis $(37.8 \pm 0.42 \mathrm{mN} / \mathrm{m})$, Lactobacillus delbrueckii $(32.5 \pm 0.70 \mathrm{mN} / \mathrm{m})$, Pseudomonas aeruginosa $(28.7 \pm 0.98 \mathrm{mN} / \mathrm{m})$ and P. fluorescens $(34.7 \pm 0.35 \mathrm{mN} / \mathrm{m})$ (Table 3). There was a direct correlation found between drop collapse, oil spreading and surface tension assays. Strains highly active in any one of these methods were active in other two methods. Similar direct correlation between drop collapse method and surface tension was reported by Bodour and Miller-Maier [20]; and direct correlation between drop collapse and oil spreading method by Youssef et al. [21]. Above earlier reports and results from this study indicated that drop collapse and oil spreading assays are easy, reliable and sensitive methods to check the biosurfactant production.

As a confirmation, 4 strains from above 5 potential strains (i.e., Bacillus megaterium, Corynebacterium kutscheri, Lactobacillus delbrueckii and Pseudomonas aeruginosa) showing positive activity in drop collapse, oil spreading and surface tension assays were already reported as potential biosurfactant producers in a different study reported by Thavasi et al. [43,44].

\section{Conclusion}

Earlier reports on screening of biosurfactant producing microbes discussed either a single method or combination of two or three methods like hemolytic assay, BATH assay, drop collapse method, oil spreading assay and surface tension measurement [20-22]. Few reports have 6 to 8 screening methods but with no surface tension measurement. Whereas, in this study six different methods were used to screen bacterial isolates for biosurfactant production and it was found that drop collapse and oil spreading methods are reliable methods to screen large number of samples for biosurfactant production because these methods require only 5-10 $\mu \mathrm{l}$ of biosurfactant solution and have direct correlation with each other as reposted in this study and in other earlier studies. After screening the strains for biosurfactant production using oil spreading and drop collapse assay, for confirmation surface tension method can be included in the screening criteria. Results from this study show that the order of suitable methods to screen biosurfactant production is surface tension measurement $>$ drop collapse assay $=$ oil spreading $>$ emulsification assay.

Compared to other earlier reports the percentage of biosurfactant producing strains isolated in this study was high $(75.2,81.77$, and $82.7 \%$, for surface tension, oil spreading and drop collapse assays, respectively). The reason for this higher percentage may be that the bacterial strains used in this study were isolated using crude oil enrichment medium which might have excluded all other bacterial strains that are not able to use crude oil for growth. Other earlier reports mentioned in this manuscript used strains isolated with nutrient rich culture medium e.g., Nutrient agar for the isolation. Thus, use of crude oil or hydrophobic carbon substrate enrichment can be used as a criterion to isolate new biosurfactant producing bacteria. In many reports crude oil degradation is directly correlated to surfactant production $[23,45]$. However, a comparative study with hydrocarbon enrichment and without hydrocarbon enrichment is needed to justify the above statement on the use of hydrophobic substrate as a criterion to isolate new biosurfactant producing bacteria.

\section{Acknowledgement}

Drs. Thavasi and Jayalakshmi thank the authorities of Annamalai University for providing the facilities and Department of Ocean Development (DOD) and Council of Scientific and Industrial Research (CSIR), Government of India for providing financial support.

\section{References}

1. Van Hamme JD, Singh A, Ward OP (2006) Physiological aspects: Part 1 in a series of papers devoted to surfactants in microbiology and biotechnology. Biotechnol Adv 24: 604-620.

2. Banat IM, Makkar RS, Cameotra SS (2000) Potential commercial applications of microbial surfactants. Appl Microbiol Biotechnol 53: 495-508.

3. Banat IM, Franzetti A, Gandolfi I, Bestetti G, Martinotti MG, et al. (2010) Microbial biosurfactants production, applications and future potential. Appl Microbiol Biotechnol 87: 427-444.

4. Franzetti A, Tamburini E, Banat IM (2010) Application of biological surface active compounds in remediation technologies. Adv Exp Med Biol 672: 121134

5. Mulligan CN (2005) Environmental applications for biosurfactants. Environ Pollut 133: 183-198.

6. Das P, Mukherjee S, Sen R (2009) Biosurfactant of marine origin exhibiting heavy metal remediation properties. Bioresour Technol 100: 4887-4890.

7. Sivapathasekaran C, Mukherjee S, Ray A, Gupta A, Sen R (2010) Artificial neural network modeling and genetic algorithm based medium optimization for the improved production of marine biosurfactant. Bioresour Technol 101: 2884 2887.

8. Kiran SG, Thomas TA, Selvin J, Sabarathnam B, Lipton AP (2010) Optimization and characterization of a new lipopeptide biosurfactant produced by marine Brevibacterium aureum MSA13 in solid state culture. Bioresour Technol 101 2389-2396.

9. Satpute SK, Banat IM, Dhakephalkar PK, Banpurkar AG, Chopade BA (2010) Biosurfactants, bioemulsifiers and exopolysaccharides from marine microorganisms. Biotechnol Adv 28: 436-450.

10. Abalos A, Vinas M, Sabate J, Manresa MA, Solanas AM (2004) Enhanced biodegradation of Casablanca crude oil by a microbial consortium in presence of a rhamnolipid produced by Pseudomonas aeruginosa AT 10. Biodegradation 15: $249-260$.

11. Cubitto MA, Moran AC, Commendatore M, Chiarello MN, Baldini MD, et al. (2004) Effects of Bacillus subtilis O9 biosurfactant on the bioremediation of crude oil-polluted soil. Biodegradation 15: 281-287.

12. Owsianiak M, Chrzanowski $Ł$, Szulc A, Staniewski J, Olszanowski A, et al. (2009). Biodegradation of diesel/biodiesel blends by a consortium of hydrocarbon degraders: Effect of the type of blend and the addition of biosurfactants. Bioresour Technol 100: 1497-1500.

13. Satpute SK, Banpurkar AG, Dhakephalkar PK, Banat IM, Chopade BA (2009) Methods for investigating biosurfactants and bioemulsifiers: a review. Crit Rev Biotechnol 30: 127-144.

14. Smyth TJP, Perfumo A, Marchant R, Banat IM (2010) Isolation and analysis of low molecular weight microbial Glycolipids. In: Handbook of hydrocarbon 
Citation: Thavasi R, Sharma S, Jayalakshmi S (2011) Evaluation of Screening Methods for the Isolation of Biosurfactant Producing Marine Bacteria. J Pet Environ Biotechnol S1:001. doi:10.4172/2157-7463.S1-001

and lipid microbiology (Timmis KN, Ed.), Springer-Verlag, Heidelberg pp 37053723.

15. Smyth TJP, Perfumo A, McClean S, Marchant R, Banat IM (2010) Isolation and analysis of lipopeptides and high molecular weight biosurfactants. In: Handbook of hydrocarbon and lipid microbiology (Timmis KN, Ed.), SpringerVerlag, Heidelberg pp 3689-3704.

16. Banat IM (1993) The isolation of a thermophilic biosurfactant producing Bacillus sp. Biotechnol Lett 15: 591-594.

17. Yonebayashi H, Yoshida S, Ono K, Enomoto H (2000) Screening of microorganisms for microbial enhanced oil recovery process. Sekiyu Gakkaishi 43: 59-69.

18. Volchenko NN, Karasev SG, Nimchenko DV, Karaseva EV (2007) Cell hydrophobicity as a criterion of selection of bacterial producers of biosurfactants. Microbiology 76: 112-114

19. Tuleva BK, Ivanov RG, Christova NE (2002) Biosurfactant production by an new Pseudomonas putida strain. Z Naturforsch 57: 356-360.

20. Bodour AA, Miller-Maier R (1998) Application of a modified dropcollapse technique for surfactant quantification and screening of biosurfactant-producing microorganisms. J Microbiol Methods 32: 273-280.

21. Youssef NH, Duncan KE, Nagle DP, Savage KN, Knapp RM, et al. (2004) Comparison of methods to detect biosurfactant production by diverse microorganisms. J Microbiol Methods 56: 339-347.

22. Afshar S, Lotfabad TB, Roostaazad R, Najafabadi AR, Noghabi AK (2008) Comparative approach for detection of biosurfactant-producing bacteria isolated from Ahvaz petroleum excavation areas in south of Iran. Ann Microbiol 58: 555-560.

23. Satpute SK, Bhawsar BD, Dhakephalkar PK, Chopade BA (2008) Assessment of different screening methods for selecting biosurfactant producing marine bacteria. Indian J Mar Sci 37: 243-250.

24. Thavasi R, Jayalakshmi S(2003)Bioremediation potential of hydrocarbonoclastic bacteria in Cuddalore harbour waters (India). Res J Chem Environ 7: 17-22.

25. Mulligan CN, Cooper DG, Neufeld RJ (1984) Selection of microbes producing biosurfactants in media without hydrocarbons. J Ferment Technol 62: 311-314.

26. Rodrigues LR, Teixeira JA, van der Mei HC, Oliveira R (2006) Isolation and partial characterization of a biosurfactant produced by Streptococcus thermophilus A. Colloids Surf B Biointerfaces 53: 105-112.

27. Rosenberg M, Gutnick D, Rosenberg E (1980) Adherence to bacteria to hydrocarbons: a simple method for measuring cell-surface hydrophobicity. FEMS Microbiol Lett 9: 29-33.

28. Betts RP, Bankers P, Banks JG (1989) Rapid enumeration of viable microorganisms by staining and direct microscopy. Lett Appl Microbiol 9: 199202

29. Jain DK, Collins-Thompson DL, Lee H, Trevors JT (1991) A dropcollapsing test for screening surfactant-producing microorganisms. J Microbiol Methods 13 271-279.

30. Morikawa M, Hirata Y, Imanaka, TA (2000) A study on the structure-function relationship of lipopeptide biosurfactants. Biochim Biophys Acta 1488: 211218.

31. Rosenberg E, Zuckerberg A, Rubinovitz C, Gutnick DL (1979) Emulsifier of Arthrobacter RAG-I: isolation and emulsifying properties. Appl Environ Microbiol 37: 402-408.

32. Yateem A, Balba MT, Al-Shayji Y, Al-Awadhi N (2002) Isolation and characterization of biosurfactant-producing bacteria from oil-contaminated soil. Soil Sediment Contam 11: 41-55
33. Bodour AA, Drees KP, Miller-Maier R (2003) Distribution of biosurfactantproducing bacteria in undisturbed and contaminated arid southwestern soils. Appl Environ Microbiol 69: 3280-3287.

34. Das K, Mukherjee AK (2005) Characterization of biochemical properties and biological activities of biosurfactants produced by Pseudomonas aeruginosa mucoid and non-mucoid strains isolated from hydrocarbon-contaminated soil samples. Appl Microbiol Biotechnol 69: 192-199.

35. Bernheimer AW, Avigad LS (1970) Nature and properties of a cytolytic agent produced by Bacillus subtilis. J Gen Microbiol 61: 361-369.

36. Carrillo PG, Mardaraz C, Pitta-Alvarez SJ, Giulietti AM (1996) Isolation and selection of biosurfactant-producing bacteria. World J Microbiol Biotechnol 12 82- 84.

37. Moran AC, Martinez AM, Sineriz F (2002) Quantification of surfactin in culture supernatant by hemolytic activity. Biotechnol Lett 24: 177- 180.

38. Walter V, Syldatk C, Hausmann R (2010) Screening concepts for the isolation of biosurfactant producing microorganisms. In: Biosurfactants: advances in Experimental Medicine and Biology (Sen R, Ed.), Springer-Verlag, Heidelberg, Vol. 672 pp 1-13.

39. Zhang Y, Miller RM (1994) Effect of Pseudomonas rhamnolipid biosurfactant on cell hydrophobicity and biodegradation of octadecane. Appl Environ Microbiol 60: $2101-2106$

40. Deziel E, Paquette G, Villemur R, Lepine F, Sailton JB, (1999) Biosurfactan production by a soil Pseudomonas strains growing on poly aromatic hydrocarbons. Appl Environ Microbiol 62: 1908-1912.

41. Franzetti A, Caredda P, Colla PL, Pintus M, Tamburini E, et al. (2009) Cultural factors affecting biosurfactant production by Gordonia sp. BS29. Int Biodeterioration Biodegrad 63: 943-947.

42. Hommel RK (1994) Formation and function of biosurfactants for degradation of water-insoluble substrates. In: Biochemistry of Microbial Degradation (Ratledge C, Ed.), Kluwer Academic Publishers, Boston p 63-87.

43. Thavasi R, Nambaru VRMS, Jayalakshmi S, Balasubramanian, $T$, Banat IM (2011) Biosurfactant production by Pseudomonas aeruginosa from renewable resources. Indian J Microbiol 51: 30-36.

44. Thavasi R, Jayalakshmi S, Banat IM (2011) Effect of biosurfactant and fertilize on biodegradation of crude oil by marine isolates of Bacillus megaterium, Corynebacterium kutscheri and Pseudomonas aeruginosa. Bioresour Techno 102: $772-778$.

45. Rahman KSM, Rahman TJ, Lakshmanaperumalsamy $P$, Marchant R, Banat IM (2003) The Potential of Bacterial Isolates for Emulsification with a Range of Hydrocarbons. Acta Biotechnol 23: 335-345. 